\title{
Model Ward dan Peppard untuk Perencanaan Strategis Sistem Informasi Bisnis Hotel
}

\author{
Wijang Widhiarso ${ }^{1,2^{*}}$, Elia Budianto Palit ${ }^{2}$ \\ ${ }^{I}$ Program Studi Teknik Informatika, STMIK Global Informatika MDP, Palembang, Indonesia \\ ${ }^{2}$ Program Studi Sistem Informasi, STMIK Global Informatika MDP, Palembang, Indonesia \\ *Kontak: wijang@mdp.ac.id, Telepon+6281373555312
}

\begin{abstract}
Abstrak- Setiap usaha yang dirintis selalu diinisiasi oleh suatu gagasan perorangan atau kelompok, gagasan ini dapat bersifat personal maupun dalam rangka mencari manfaat dan keuntungan. Sedangkan, strategi merupakan suatu cara untuk mewujudkan gagasan yang telah terbentuk. Penelitian ini bertujukan untuk menemukan dan memperjelas gagasan pemilik usaha dalam bentuk visi, misi, dan pandangan lain yang berkaitan dengan Hotel XYZ. Hotel XYZ merupakan hotel bintang dua yang berlokasi di Kota Palembang dimana kompetisi dengan merek hotel ekonomis dan digital disruption tidak dapat dihindari pada saat penelitian ini dibuat, sehingga diperlukan suatu strategi yang menghasilkan usulan strategi bisnis dan SI/TI. Berdasarkan gagasan tersebut, penulis merumuskan strategi sistem informasi dengan mengevaluasi indikator pencapaian gagasan, analisa lingkungan bisnis dan analisa SI/TI, serta memproyeksikan SI/TI yang ada untuk mencapai gagasan pemilik Hotel XYZ.
\end{abstract}

Abstract - Every business always initiated by an individual or group idea in the context of seeking benefits and profits. Meanwhile, strategy is a way to realize the ideas. This research aims to find and clarify the ideas of business owners in the form of a vision, mission, and other views related to XYZ Hotel. Hotel XYZ is a two-star hotel located in Palembang City where competition with economical hotel brands and digital disruption cannot be avoided at the time this research was made, so needs a business strategy and strategy IS / IT. Based on these ideas, the authors formulate an information system strategy by evaluating the achievement indicators of ideas, analyzing business environment and IS / IT analysis, and projecting existing IS / IT to achieve the idea of XYZ Hotel owner using Ward dan Peppard method. .

\section{PENDAHULUAN}

Hal ini yang penulis perlu pastikan pada penelitian ini, untuk menemukan pandangan pemilik terhadap organisasi juga lingkungan bisnis baik internal maupun eksternalnya, bagaimana ia menyikapi tantangan dan persoalan internal organisasi, serta bagaimana pemilik memimpin, mengarahkan dan memperlakukan organisasi untuk mencapai gagasan yang telah dibentuk semula. Fakta-fakta baru ditemukan dalam kegiatan wawancara, hasil analisa wawancara dan pengamatan.

Ide awal Hotel XYZ dibangun pertama kali dengan gagasan mencari kesempatan baru setelah berhasil menjalankan usaha yang dirintis sebelumnya. Ide tersebut muncul yang berasal dari latar belakang pemiliknya yang memiliki falsafah dan cita-cita mulia yaitu ingin membuka lapangan pekerjaan dan menjadi berkat bagi orang lain. Pemilik beranggapan bahwa usaha dibidang perhotelan merupakan jenis usaha yang menguntungkan secara strategis, karena pemilik memiliki latar belakang pendidikan yang sesuai yaitu SMK perhotelan.

Penulis menemukan fakta bahwa Hotel XYZ berkepemilikan tunggal, sehingga gagasan yang dicanangkan merupakan gagasan seorang. Gagasan yang dibentuk tidak dituangkan 
kedalam dokumen perencanaan ataupun strategi manajemen melainkan kepada keputusan, perubahan perilaku organisasi dan kebiasaan administratif. Untuk saat ini, pemilik sedang diperhadapkan dengan kondisi yang menyebabkan diperlukannya usaha lebih, dalam menjaga dan meningkatkan pendapatan. Kondisi tersebut adalah pelunasan kewajiban bank.

Fakta lain yang juga ditemukan yaitu pemilik merasakan dampak dari maraknya penggunaan manajamen hotel virtual dan OTA, dimana bisnis tersebut mengambil peran banyak dalam lingkungan bisnis perhotelan di Kota Palembang, sehingga hal ini sangat mempengaruhi pemilik dan manajer Hotel XYZ. Dampak yang dirasakan oleh pemilik ini merupakan sebuah digital disruption seperti yang dijelaskan oleh John Ward dan Peppard pada bukunya yang berjudul The Strategic Management of Information System 4rd edition (2016). Digital disruption yang dimaksud merupakan gangguan yang diakibatkan dari digitalisasi proses, dan market.

Berdasarkan uraian diatas, maka penulis memutuskan untuk melakukan pendekatan dengan perencanaan strategis. Namun, adapun kesulitan yang dihadapi yaitu tidak ditemukannya komitmen dan kerjasama yang elaboratif dari pemilik, yang disebabkan oleh gagalnya penyampaian maksud penelitian. Oleh karena itu, berdasarkan latar belakang pemilik, gagasan yang dibentuk untuk Hotel XYZ, persoalan yang dihadapi, serta fakta yang ditemukan, maka penelitian yang diajukan hanya sebatas analisa dan perancangan strategi dari sudut pandang SI/TI.

Untuk menggapai kesuksesan penelitian, penulis memerlukan literatur mengenai perencanaan strategis sistem informasi dengan metode Ward dan Peppard tahun 2016, literatur strategi bisnis hotel, literatur strategi digital dan literatur lain yang berkaitan dengan akomodasi penginapan di Kota Palembang. Literatur ini membantu dalam memberikan pemahaman mengenai bisnis perhotelan dan ide yang dapat usulkan pada penelitian ini. Pendapat, dan keterangan dari pegawai hotel untuk memperkuat hasil analisis.

\section{Metode Penelitian}

\section{A. Tahapan Penelitian}

Penelitian ini terdiri dari tiga (3) tahapan utama yaitu tahapan masukan, tahapan proses dan tahapan keluaran. Pada tahap pemasukan terdapat dua aktivitas yaitu mengumpulkan data dan memasukan data untuk dianalisa strategi kompetitor dan kesenjangan keinginan pemilik dengan lingkungan bisnis. Sesudah melakukan analisa maka masuk ke tahap metodologi Ward dan Peppard yang terdiri dari lingkungan bisnis eksternal, lingkungan bisnis internal, lingkungan SI/TI internal dan lingkungan SI/TI Eksternal. 


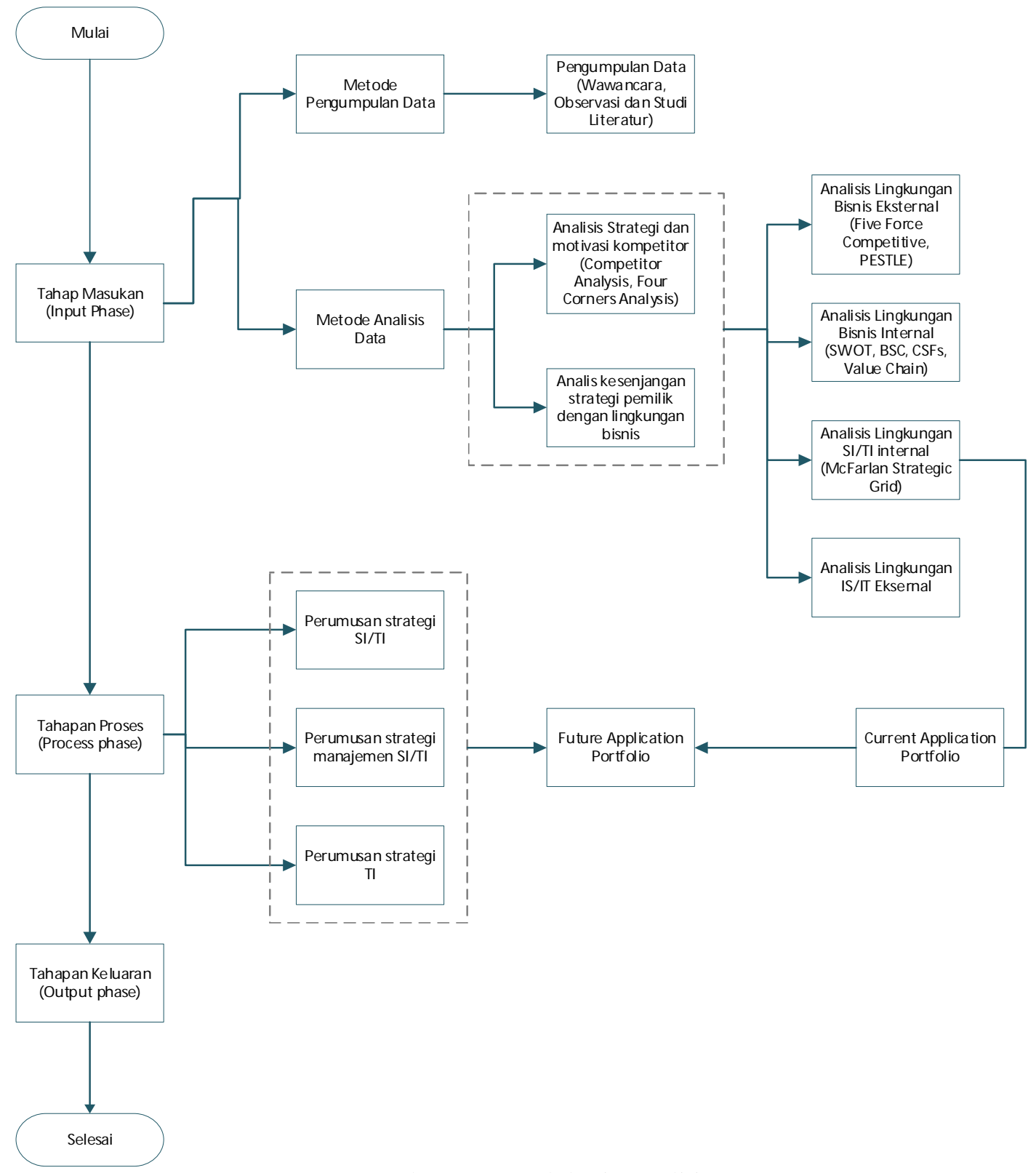

Gambar 1. Metodologi Penelitian

\section{Pendekatan Penelitain}

Berdasarkan latar belakang, rumusan masalah, ruang lingkup dan landasan teori yang telah dipahami maka pendekatan penelitian yang dirasa tepat adalah Perencanaan Strategis Sistem Informasi dengan metodologi Ward dan Peppad.Metodologi tersebut dirasa tepat karena telah membahas digital disruption, strategi digital dan tantangan mendapatkan komitmen manajemen puncak. 


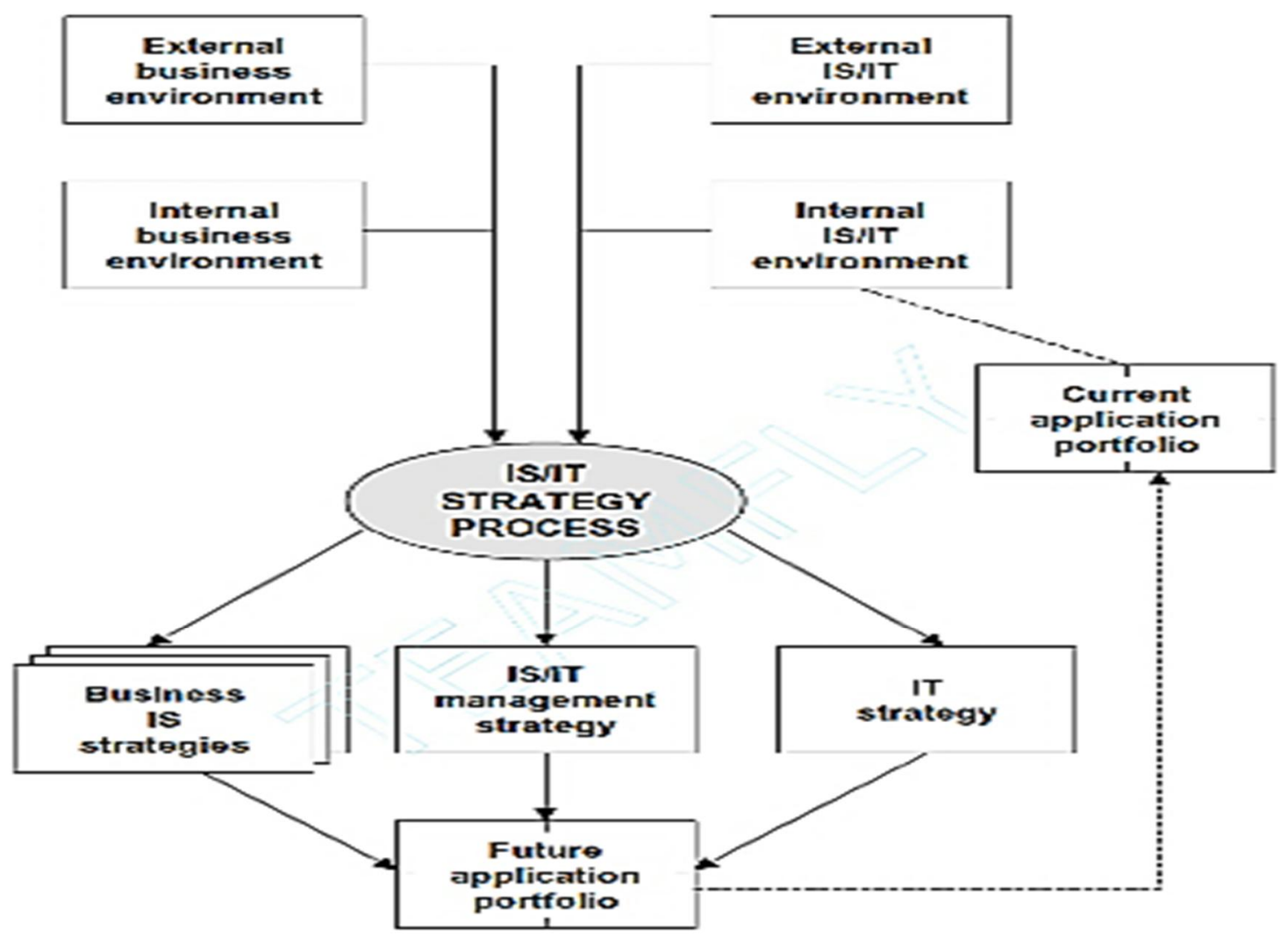

Gambar 2. Pendekatan Penelitian

\section{B. Penelitian Terdahulu}

Penelitian terdahulu dapat digunakan untuksumber pembanding dengan penelitian yang sedang penulis lakukan. Penelitian di bawah ini merupakan penelitian yang mendekati dengan judul penelitian.

Tabel 1. Penelitian Terdahulu

\begin{tabular}{|c|c|c|}
\hline Peneliti & Judul & Hasil \\
\hline $\begin{array}{l}\text { Elizabeth, Agus } \\
\text { Arifin }\end{array}$ & \begin{tabular}{lrr}
\multicolumn{2}{l}{ Perancangan } & Sistem \\
Informasi Strategik Pada \\
Ukm Xyz Untuk \\
Memaksimalkan Pemasaran \\
\multicolumn{2}{l}{ DanEfisiensi Biaya }
\end{tabular} & $\begin{array}{l}\text { Hasil yang diperoleh UKM } \\
\text { XYZ telah menunjukkan } \\
\text { komitmennya untuk } \\
\text { menjadiyang terbaik dalam } \\
\text { bisnis r minuman } \\
\text { tradisional. }\end{array}$ \\
\hline $\begin{array}{l}\text { M. Wildan Satrio U, Heri } \\
\text { Risnanto, Siti Naza Rayani, } \\
\text { Miftahul Fahmi, } \\
\text { Nurbojatmiko,Asep Fajar, } \\
\text { Rinda Hesti Kusumatingtyas }\end{array}$ & $\begin{array}{lcr}\text { Analisis } & \text { Strategi } & \text { Bisnis } \\
\text { Sistem } & \text { Informasi } & \text { Jasa } \\
\text { PenyediaPerjalanan Wisata }\end{array}$ & $\begin{array}{l}\text { Terdapat fitur yang } \\
\text { memberikan diferensiasi } \\
\text { yang berasal dari analisis } \\
\text { value chain }\end{array}$ \\
\hline $\begin{array}{l}\text { Muhammad Bayu Nugraha, } \\
\text { Gyansar Pralebda, Renny } \\
\text { Sari Dewi }\end{array}$ & \begin{tabular}{lr}
\multicolumn{2}{l}{ Perencanaan Strategis } \\
Sistem Informasi & Pada \\
Universitas & XYZ \\
MenggunakanMetode & Ward \\
and Peppard &
\end{tabular} & $\begin{array}{lll}\text { Hasil } & \text { yangdiperoleh } \\
\text { berupa dokumen } & \text { ISSP } \\
\text { sangatlah penting } & \text { pada } \\
\text { universitas XYZ. }\end{array}$ \\
\hline
\end{tabular}

Wijang, et., al (Model Ward dan Peppard untuk Perencanaan Strategis Sistem Informasi Bisnis Hotel) 


\begin{tabular}{|c|c|c|}
\hline Andry Adrian Tirana & $\begin{array}{lr}\text { Information } & \text { System } \\
\text { Strategic PlanningAt PT } \\
\text { EP-TEC } & \text { Solutions } \\
\text { Indonesia } & \end{array}$ & $\begin{array}{l}\text { Aplikasi strategis bernama } \\
\text { KMS, High potential } \\
\text { CRM, keyapplication web- } \\
\text { sahred folder, support } \\
\text { multimedia application }\end{array}$ \\
\hline $\begin{array}{l}\text { I Wayan Widi Karsana, I } \\
\text { Made Candiasa,Gde Rasben } \\
\text { Dantes }\end{array}$ & $\begin{array}{l}\text { PerencanaanStrategis } \\
\text { Sistem Informasi dan } \\
\text { Teknologi Informasi } \\
\text { Menggunakan Framework } \\
\text { Ward and Peppard pada } \\
\text { Sekolah Bali Kiddy I } \\
\text { Wayan }\end{array}$ & $\begin{array}{l}\text { Membentuk bagian ICT } \\
\text { untuk menyelesaikan } \\
\text { permasalahan SI/TI }\end{array}$ \\
\hline
\end{tabular}

\section{HASIL DAN PEMBAHASAN}

\section{A. Gap Analysis}

Gap Analysis pada penelitian ini digunakan untuk melihat apa saja yang menjadi kesenjangan pemikiran pemilik Hotel XYZ dengan lingkungan bisnis dan SI/TI. Hal ini akan menjadi acuan pada penelitian ini. Penulis melakukan identifikasi terhadap motivasi dalam pengambilan sikap dan keputusan sebagai berikut.

Tabel 2. GAP Analysis

\begin{tabular}{|c|c|c|}
\hline Indentifikasi 1 & Gap & \\
\hline $\begin{array}{l}\text { - Tindakan disiplin dan } \\
\text { arahan secara langsung } \\
\text { oleh pemilik. } \\
\text { - Pemilik memiliki visi } \\
\text { untuk membuka lapangan } \\
\text { pekerjaan. } \\
\text { - Pemilik merasa perlu } \\
\text { memperbaiki SDM dan } \\
\text { manajemen. }\end{array}$ & $\begin{array}{l}\text { - Menyalurkan energi } \\
\text { dan sumber daya } \\
\text { pemikiran pegawai } \\
\text { kepada hal yang } \\
\text { produktif, dimana } \\
\text { produktif tersebut } \\
\text { dapat memajukan } \\
\text { Hotel XYZ hingga } \\
\text { tercapai visinya. }\end{array}$ & $\begin{array}{l}\text { - Pemilik ingin } \\
\text { mempertahankan dan bukan } \\
\text { memberhentikan pegawai. } \\
\text { - Pemilik tidak merekrut banyak } \\
\text { pegawai namun hanya mereka } \\
\text { yang mau belajar dan dapat } \\
\text { bekerjasama. }\end{array}$ \\
\hline $\begin{array}{lr}\text { - Pemilik } & \text { ingin pegawai } \\
\text { dapat bekerja } & \text { seperti } \\
\text { pemilik tersebut bekerja } \\
\text { dengan memiliki insting } \\
\text { bisnis. } & \\
\text { - Pemilik } & \text { ingin } \\
\text { meningkatkan kualitas } \\
\text { dan kemampuan } \\
\text { pegawai. }\end{array}$ & $\begin{array}{l}\text { - Data, pemahaman } \\
\text { akan } \\
\text { pengetahuan, } \\
\text { wawasan akan bisnis } \\
\text { dan teknologi terbaru, } \\
\text { serta pengalaman } \\
\text { dalam berbisnis akan } \\
\text { memberikan } \\
\text { internalisasi dan } \\
\text { sebuah karifan. } \\
\end{array}$ & $\begin{array}{l}\text { - Cara termudah } \\
\text { menjelaskan untuk } \\
\text { keinginan hati ialah dengan } \\
\text { memberikan sebuah teladan } \\
\text { dalam hal ketelatenan dan } \\
\text { ketenangan. Kepemimpinan } \\
\text { yang mudah dimengerti dan } \\
\text { bimbingan yang terkait dengan } \\
\text { kehidupan sehari-hari pegawai. }\end{array}$ \\
\hline $\begin{array}{l}\text { - Pemilik memutuskan } \\
\text { untuk membeli sebuah } \\
\text { sistem manajemen hotel } \\
\text { - Sistem manajemen hotel } \\
\text { tersebut memberikan } \\
\text { sebuah pelajaran }\end{array}$ & $\begin{array}{l}\text { - Perlu adanya wawasan } \\
\text { untuk melihat } \\
\text { bagaimana bisnis } \\
\text { perhotelan modern dan } \\
\text { mapan tersebut bekerja. } \\
\text { Sertar bagaimana }\end{array}$ & $\begin{array}{l}\text { Pemilik belum menyadari } \\
\text { pentingnya sebuah data dan } \\
\text { informasi dalam melihat tren } \\
\text { dan sebagai dukungan dalam } \\
\text { pengambilan keputusan }\end{array}$ \\
\hline
\end{tabular}




\begin{tabular}{|c|c|c|}
\hline 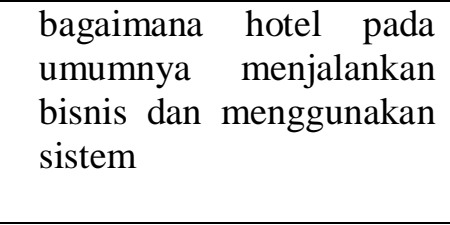 & $\begin{array}{l}\text { mereka menghadapi } \\
\text { persaingan merek hotel } \\
\text { ekonomis termasuk } \\
\text { dalam musim perang } \\
\text { tarif. }\end{array}$ & \\
\hline $\begin{array}{l}\text { - Pemilik menyesuaikan } \\
\text { kepada cara kerja sistem } \\
\text { dan bukan sistem yang } \\
\text { menyesuaikan gaya } \\
\text { berbisnis pemilik Hotel } \\
\text { XYZ. } \\
\text { - Peluang memperoleh } \\
\text { manfaat dari sistem } \\
\text { informasi yang modern } \\
\text { - Pemilik ingin pegawai } \\
\text { dapat bekerja produktif }\end{array}$ & 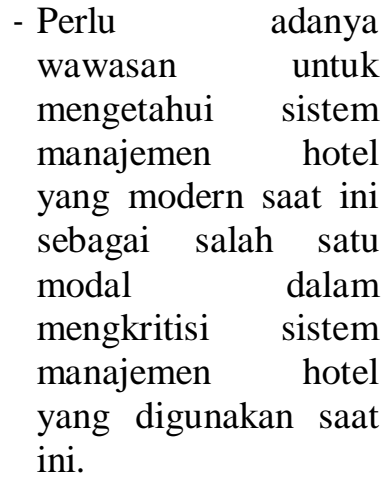 & $\begin{array}{l}\text { - Sistem manajemen Hotel XYZ } \\
\text { saat ini dibuat berdasarkan } \\
\text { pemintaan hotel sebelumnya } \\
\text { yang merupakan klien } \\
\text { programmer. } \\
\text { - Sistem informasi yang modern } \\
\text { mungkin akan mengotomasi } \\
\text { proses sehingga mengurangi } \\
\text { beban kerja pegawai }\end{array}$ \\
\hline
\end{tabular}

\section{B. Critical Success Factor}

Setelah melakukan analisis Balanced Scorecard, penulis melakukan analisa terhadap faktor yang menentukan kesukseskan pencapaian tujuan dan tolak ukur tersebut dengan Critical Success Factor. Tahap ini akan menjadi acuan dalam merumuskan strategi SI/TI nanti.

Tabel 3. Critical Success Factor

\begin{tabular}{|c|c|c|}
\hline Tujuan & Tolak Ukur & CSF \\
\hline $\begin{array}{lr}\begin{array}{l}\text { Meningkatkan } \\
\text { mendapatkan }\end{array} & \text { okupansi dan } \\
\text { sebesar-besarnya } & \end{array}$ & $\begin{array}{lr}\text { Keuntungan } & \text { Hotel } \\
\text { XYZ bertambah, } & \text { dimana rasio biaya } \\
\text { pengeluaran } & \text { lebih } \\
\text { rendah } & \text { dari } \\
\text { pendapatan dalam } \\
\text { mendapatkan okupansi } \\
\text { yang tinggi. }\end{array}$ & $\begin{array}{l}\text { Tersedianya cara untuk } \\
\text { mendapatkan okupansi yang } \\
\text { tinggi setiap harinya yang } \\
\text { biaya yang rendah untuk } \\
\text { mendapatkan hal tersebut. }\end{array}$ \\
\hline $\begin{array}{l}\text { Memberikan akomodasi kepada } \\
\text { masyarakat Kota Palembang, } \\
\text { luar kota dan luar negeri }\end{array}$ & $\begin{array}{l}\text { Hotel XYZ dapat } \\
\text { dikenal dan diketahui } \\
\text { oleh masyarakat } \\
\text { Indonesia, serta ada } \\
\text { sebuah fasilitas untuk } \\
\text { reservasi kamar selain } \\
\text { media OTA }\end{array}$ & $\begin{array}{ll}\text { Tersedianya media } & \text { untuk } \\
\text { mempublikasikan, } & \text { Hotel } \\
\text { XYZ, dan menfasilitasi } \\
\text { calon tamu harvani umtuk } \\
\text { memesan kamar secara } \\
\text { langsung. }\end{array}$ \\
\hline $\begin{array}{l}\text { Memberikan sebuah tempat } \\
\text { yang nyaman, bersih dan ramah- } \\
\text { tamah }\end{array}$ & \begin{tabular}{lr}
\multicolumn{2}{l}{ Tidak ada keluhan dari } \\
tamu, & serta \\
memberikan & review \\
yang positif & terhadap \\
Hotel XYZ. &
\end{tabular} & $\begin{array}{l}\text { Tersedianya informasi } \\
\text { kepuasan tamu dalam } \\
\text { memperoleh kenikmatan. }\end{array}$ \\
\hline Bertambahnya pegawai & 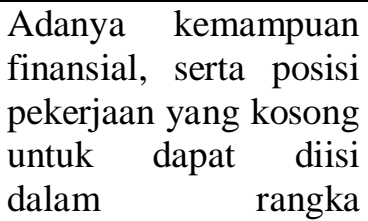 & $\begin{array}{l}\text { Tersedianya } \\
\text { keuangan dan informasi } \\
\text { karakteristik tenaga kerja } \\
\text { yang diperlukan. }\end{array}$ \\
\hline
\end{tabular}




\begin{tabular}{|l|l|l|}
\hline & $\begin{array}{l}\text { meningkatkan } \\
\text { produktifitas Hotel } \\
\text { XYZ. }\end{array}$ & \\
\hline $\begin{array}{l}\text { Bekerja secara efesien dan } \\
\text { efektif, } \\
\text { menghidupkan }\end{array}$ & $\begin{array}{l}\text { Bertambahnya informasi } \\
\text { pegawai harus sejalan } \\
\text { dengan produktifitas } \\
\text { yang baik dan rutin antar } \\
\text { pegawai, maupun pegawai } \\
\text { dengan pimpinan. }\end{array}$ & $\begin{array}{l}\text { Tersedianya tinggi juga pada } \\
\text { performa pegawai serta hasil } \\
\text { evaluasi terhadap strategi } \\
\text { bisnis dan SI/TI. }\end{array}$ \\
\hline $\begin{array}{l}\text { Memiliki berbagai cabang di } \\
\text { Kota Palembang dan serta } \\
\text { membuka lapangan pekerjaan } \\
\text { seluas-luasnya. }\end{array}$ & $\begin{array}{l}\text { Mengetahui lokasi } \\
\text { strategis yang berada } \\
\text { di Kota Palembang, } \\
\text { serta predikisi jumlah } \\
\text { pegawai } \\
\text { dibutuhkan. }\end{array}$ & $\begin{array}{l}\text { Tersedianya informasi hasil } \\
\text { laporan perencanaan bisnis } \\
\text { di Kota Palembang. }\end{array}$ \\
\end{tabular}

\section{Value Chain}

Value Chain atau rantai nilai digunakan sebagai alat untuk memetakan proses perolehan nilai yang dihasilkan oleh Hotel XYZ kepada tamu yang menginap maupun yang menggunakan jasa layanan Hotel XYZ. Diharapkan dengan adanya pemetaan rantai nilai dapat memberikan gambaran bagaimana Hotel XYZ menghasilkan nilai pada bisnisnya pada setiap kegiatan utama maupun kegiatan sekunder.

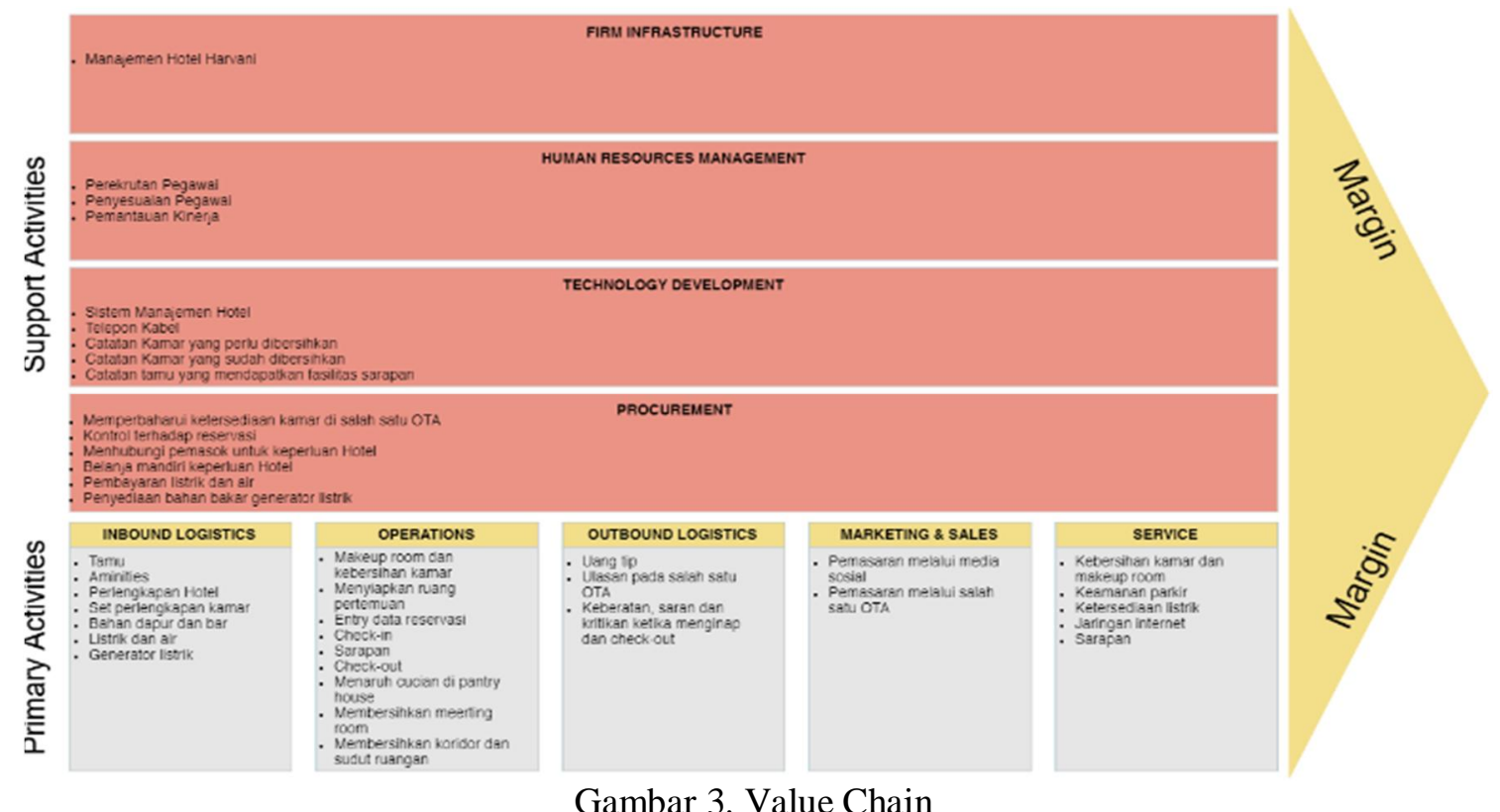

\section{Five Forces Porter}

Five Forces Porter penulis gunakan untuk menganalisa lima kekuatan asing yang mempengaruhi kompetisi bisnis perhotelan dengan bisnis Hotel XYZ saat ini.

Persaingan perusahaan sejenis

- Persaingan penginapan dirasakan oleh Hotel XYZ, dimana terdapat oknum yang mencoba melakukan pemesanan kamar fiktif. Hal tersebut dapat merugikan ketika full booking, karena terdapat calon tamu 
sesungguhnya yang ingin menginap di Hotel XYZ. Namun hal tersebut diatasi dengan menutup pembayaran pay at hotel via OTA.

- Merek hotel ekonomis yang berada dibawah naungan manajemen hotel virtual dirasa pemilik Hotel XYZ merusak harga pasaran penginapan. Hal tersebut juga membuat hotel virtual menjadi trend setter untuk segmen hotel dengan harga yang ekonomis.

- Promo oleh merek hotel ekonomis dengan sistem poin untuk mendapatkan penginapan secara cuma-cuma, cukup efektif untuk menarik perhatian pasar penginapan.

- Terdapat hotel yang relatif lebih murah dari Hotel XYZ dan tidak menggunakan merk hotel ekonomis. Hotel-hotel tersebut berada di kawasan kecamatan Ilir Timur II, Kota Palembang.

Ancaman masuknya pesaing baru

- Pejabat politik dan pengusaha yang telah eksis dapat membuka hotel baru dikawasan yang dirasa menguntungkan. Hal tersebut biasa dilakukan untuk mempersiapkan setelah masa jabatan habis atau pensiun.

- Peluang dibukanya hotel dan penginapan yang baru oleh manajemen hotel virtual dan jasa sewa layanan liburan. Google Trends menyebutkan bahwa merek hotel ekonomis yaitu OYO Rooms dan RedDoorz tumbuh sembilan kali lipat, sedangkan dan merek jasa sewa layanan liburan Airbnb sebesar tiga kali lipat. Data dari Google Trends tersebut diambil dari tahun 2015 hingga tahun 2019 di wilayah Asia Tenggara.

- Upaya peningkatan pariwisata oleh pemerintah Indonesia akan memberikan kesempatan bagi pengusaha dan pemodal untuk mengembangkan usaha dibidang pariwisata dan penginapan.

Ancaman layanan subtitusi

- Layanan penginapan kost harian dapat mengancam terutama untuk calon penghuni hotel ekonomis yang membutuhkan penginapan saja dengan harga yang lebih terjangkau dari Hotel XYZ.

- Terdapat hotel disekitar kawasan Hotel XYZ yang tidak menggunakan jasa manajemen hotel virtual dengan merek yang ternama dan fasilitas yang lebih banyak dari Hotel XYZ.

- Hotel berbintang tiga keatas menjadi pilihan alternatif bagi masyarakat yang menginginkan fasilitas dan layanan yang lebih banyak dari Hotel XYZ.

Kekuatan tawar menawar konsumen

- Tamu Hotel XYZ yang merupakan kenalan atau relasi dapat diberikan waktu dalam menunda pembayaran.

- Tawar menawar calon pengguna layanan penginapan, ruang pertemuan atau keduanya pada Hotel XYZ dapat terjadi jika calon pengguna layanan Hotel XYZ tersebut melakukan penawaran.

- Manajer selalu mendorong pegawai Hotel XYZ untuk menawarkan kamar deluxe kepada tamu yang akan menginap agar Hotel XYZ mampu memperoleh keuntungan lebih.

- Menaikan harga dari rate normal kepada dapat dilakukan pegawai Front Office, terutama ketika tamu yang akan menginap mendapat harga yang terjangkau saat high season.

- Calon tamu Hotel XYZ yang menggunakan jasa layanan OTA dapat memperoleh harga terjangkau saat high season jika pegawai Hotel XYZ tidak cukup cepat merespon terhadap kenaikan harga pasaran hotel.

- Perpajangan waktu penginapan saat high season dapat dilakukan oleh tamu yang menginap, hal tersebut dapat menjadi tawar menawar Hotel XYZ ketika ada tamu yang akan menginap yang telah mereservasi kamar tersebut. 
- Tamu dapat hanya menginap siang hari saja atau day use, sehingga dapat mengancam terjadinya penjualan kamar tanpa sepengetahuan manajer dan pemilik hotel.

Kekuatan tawar menawar pemasok

- Program deposit menjadikan Hotel XYZ berlangganan ke salah satu OTA dengan syarat yang telah ditentukan OTA tersebut. Salah satu syaratnya adalah tidak dapat menggunakan OTA lain.

- Hotel XYZ menggunakan satu-satunya pemasok sabun, shampo, sikat gigi yang berlokasi di Kota Palembang.

- Jasa laundry yang digunakan Hotel XYZ bukanlah satu-satunya jasa yang ada di Kota Palembang, sehingga ada persaingan antar perusahaan laundry membuat pemilik dan manajer Hotel XYZ dapat memilih alternatif lain.

\section{E. Competitor Analysis}

Competitor Analysis atau disebuh juga sebagai competitive analysis, penulis gunakan untuk memetakan kompetitor untuk melihat apa yang mereka miliki dan perkiraan apa peluang yang akan diambil dikemudian hari.Peluang dan model bisnis yang dimiliki akan menggambarkan kemana ia akan mengarah atau menggerakan strateginya. Berikut keempat kompetitor dan penjelasan penulis alasan memilih kompetitor ini.

\begin{tabular}{|c|c|c|c|c|}
\hline Companies & OYO Rooms & RedDoorz & Airbnb & Zuri Express Palembang \\
\hline \multicolumn{5}{|l|}{ Company Background } \\
\hline Company Profile & $\begin{array}{l}\text { Didrikan di India pada tahun } 2013 \\
\text { deh Ritesh Agarwal. }\end{array}$ & $\begin{array}{l}\text { Didirikan di Indoensia pada tahun } \\
2015 \text { dengan Kantor pusat di } \\
\text { negara Singapura. CEO bernama } \\
\text { Amit Saberwal. }\end{array}$ & $\begin{array}{l}\text { Berkantor pusat di San Fransisco } \\
\text { dan didrikan pada tahun } 2008 \\
\text { dengan CEO bernama Brian } \\
\text { Chesky. }\end{array}$ & $\begin{array}{l}\text { Merupakan bagian dari ZHM atau } \\
\text { Zuri Hotel Management dengan } \\
\text { kantor pusat di Jakarta Pusat. }\end{array}$ \\
\hline Key Competitive Advantage & $\begin{array}{l}\text { 1. Harga terjangkauu } \\
\text { 2.Jaringan besarar dengan merek } \\
\text { oYo pada setiap jaringannya. } \\
\text { 3. Menggunakan teknologl aplikasi } \\
\text { bergerak sebagal pasar digtal, } \\
\text { sistem reservasi dan pembayaran. } \\
\text { 4. Pertumbuhan jaringan hotel } \\
\text { tercepat. } \\
\text { 5. Pemasaran di berbagai platform } \\
\text { 6. Mengendarai hotel yang sudah } \\
\text { ada. }\end{array}$ & $\begin{array}{l}\text { 1. Harga terjangkau. } \\
\text { 2.Jaringan terbesar di Asia } \\
\text { Tenggara derngan merek RedDoorz } \\
\text { peda setiap jaringannya. } \\
\text { 3. Menggunakan teknologi aplikasi } \\
\text { bergerak sebagal pasar digtal, } \\
\text { sistem reservasi dan pembayaran. } \\
\text { 4. . kupansi nomor satu di Asia } \\
\text { Tenggara. } \\
5 . \text { Memilki model bisnis } \\
\text { ekosistem. } \\
\text { 6. Mengendarai hotel yang sudah } \\
\text { ada. }\end{array}$ & 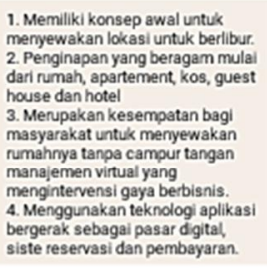 & $\begin{array}{l}\text { 1. Memilliki merek dengan nama } \\
\text { besar. } \\
2 \text { Manajemen yang mapan dan } \\
\text { tata kelola yang balk. } \\
\text { 3. Jaringan manajemen yang besar. } \\
\text { 4. Memiliki modal yanng mumpuni } \\
\text { untuk menjalankan bisnis. }\end{array}$ \\
\hline \multicolumn{5}{|l|}{ Market Information } \\
\hline Target Market & $\begin{array}{l}\text { 1. Ingin mencari hotel ekonomis } \\
\text { dengan bintang dua atau utiga. } \\
\text { 2.Mudah di dapatkan diberbagai } \\
\text { platform baik web maupun aplikasi } \\
\text { oTA } \\
\text { 3. Ingin mencari harga terjangkau. }\end{array}$ & $\begin{array}{l}\text { 1. Ingin mencari hotel dengan } \\
\text { ekosistem dan standard khas } \\
\text { RedDoorz } \\
\text { 2. Ingin mencari harga terjangkau } \\
\text { dan nilai tambah hain sepenti poin. } \\
\text { 3. Ingin mencari harga terjangkau. }\end{array}$ & $\begin{array}{l}\text { 1. Ingin mencari lokasi berlibur. } \\
\text { 2. Ingin mencari rumah untuk } \\
\text { mengakomodasi banyak tamu } \\
\text { yang menginap. } \\
\text { 3. Ingin mencari pengalaman } \\
\text { liburan dan komunitas yang ramah. }\end{array}$ & $\begin{array}{l}\text { 1. Ditargetkan pada konsumen } \\
\text { yang menginginkan fasilitas dan } \\
\text { layanan lebih dari sekedar kamar } \\
\text { penginapan. } \\
2 \text { Untuk konsumen yang } \\
\text { menginginkan penginapan yang } \\
\text { nyaman untuk longstay. }\end{array}$ \\
\hline Marketing Strategy & $\begin{array}{l}\text { Dipasarkan seluas-luasnya, dan } \\
\text { pemitk Hotel dapat memsarkan } \\
\text { sendit juga. }\end{array}$ & $\begin{array}{l}\text { Dipasarkan oleh RedDoorz melalui } \\
\text { ekosistem bisnis dan tim } \\
\text { marketingrya. }\end{array}$ & $\begin{array}{l}\text { Dipasarkan oleh Airtonb melalui } \\
\text { platform aplikasinya. }\end{array}$ & $\begin{array}{l}\text { Diposarkan oleh zuri hotel } \\
\text { management. }\end{array}$ \\
\hline
\end{tabular}




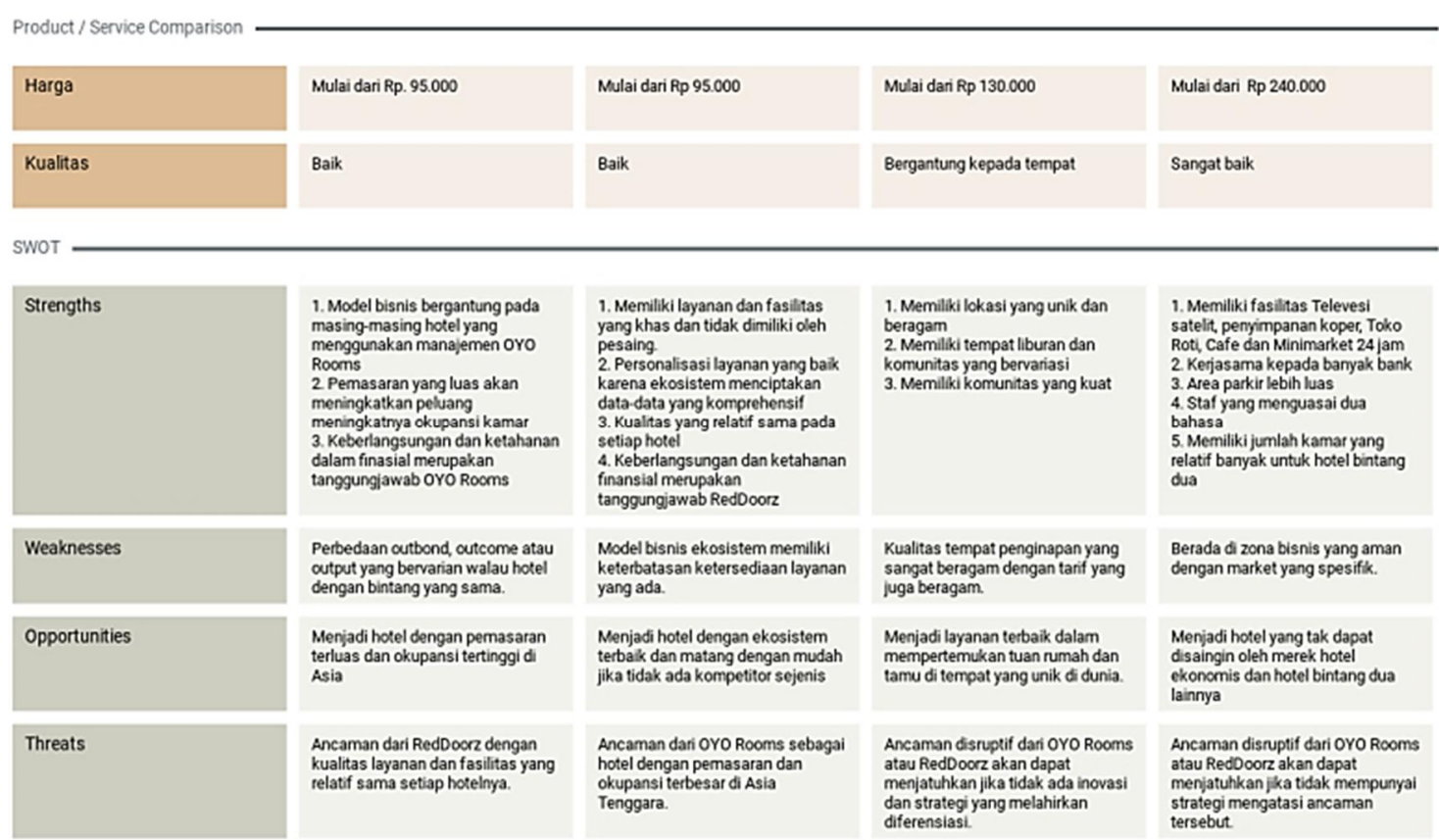

Gambar 4. Competitor Analysis

\section{F. Four Corner Analysis}

Four Corner Analysis penulis gunakan untuk menganalisa PT Trinusa Travelindo atau penulis tuliskan sebagai Traveloka untuk menggambarkan skema apa yang akan dilakukan dalam menghadapi strategi merek hotel ekonomis. Strategi yang kemungkinkan akan dilakukan oleh Traveloka kedepan ialah meningkatkan kematangan terhadap pemberian deposit. 


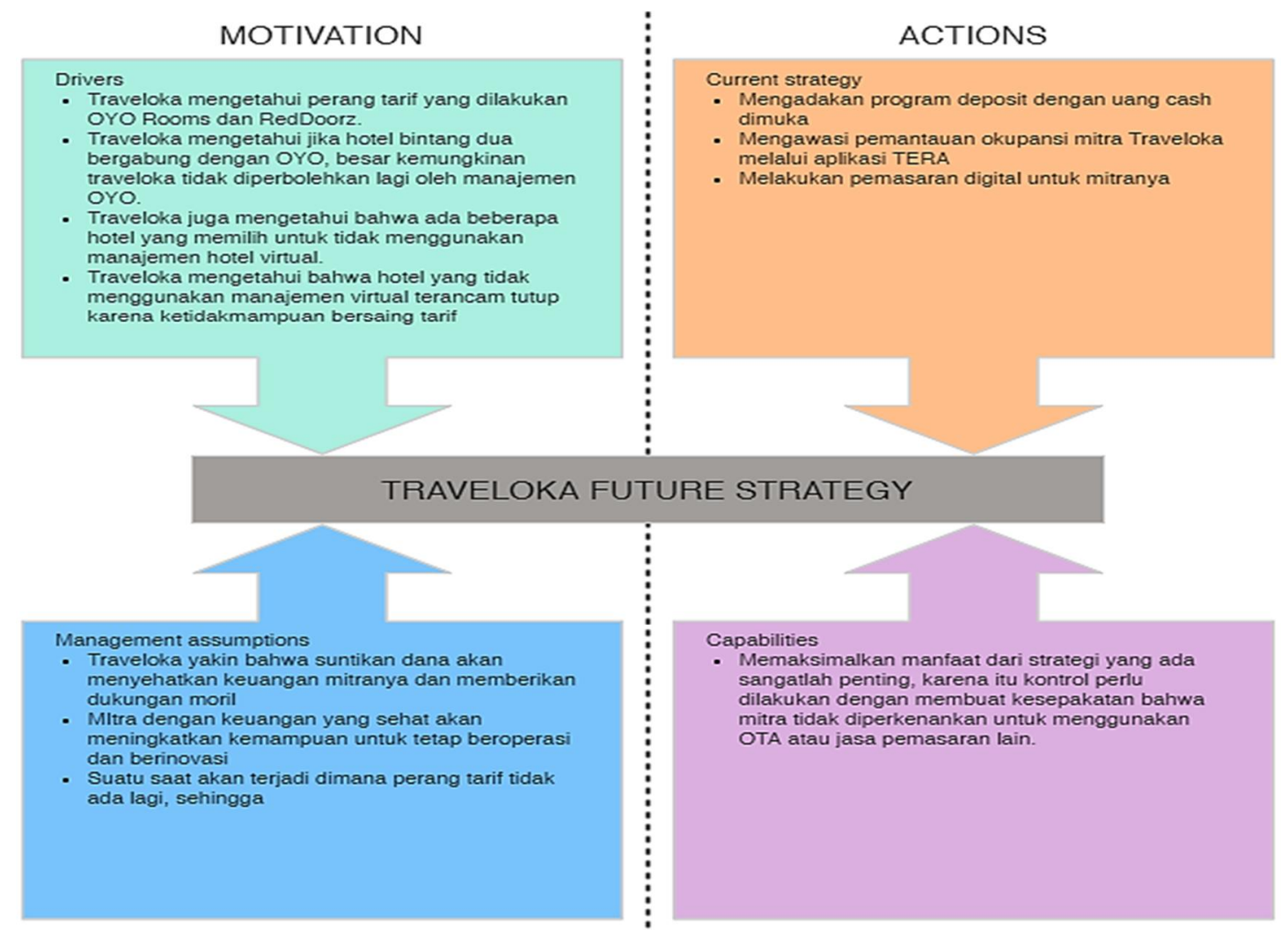

Gambar 5. Four Corner Analysis

\section{G. Current Application Portfolio}

Perangkat lunak pada Hotel XYZ, penulis petakan kedalam Strategic Grid McFarlan sebagai Current Application Portfolio.

\begin{tabular}{|l|l|}
\hline Strategic & High Potential \\
\hline TERA Traveloka & $\begin{array}{l}\text { Whatsapp, } \\
\text { Instagram, } \\
\text { Facebook }\end{array}$ \\
\hline Sistem manajemen & $\begin{array}{l}\text { Microsoft Office, } \\
\text { hotel, } \\
\text { Gmail, } \\
\text { Traveloka, } \\
\text { Telepon Seluler, } \\
\text { Whatsapp }\end{array}$ \\
\hline Key Operational & \\
\hline
\end{tabular}

Gambar 6. Competitor Analysis

\section{H. Strategi Bisnis}

I. Strategi Sistem Informasi dan Digital

J. Future Application Portfolio

The heading of the References section must not be numbered. All reference items must be in 8 pt font. Please use Regular and Italic styles to distinguish different fields as shown in the References section.Number the reference items consecutively in square brackets (e.g. [1]). 
When referring to a reference item, please simply use the reference number, as in [2]. Do not use "Ref. [3]" or "Reference [3]" except at the beginning of a sentence, e.g. "Reference [3] shows ...". Multiple references are each numbered with separate brackets (e.g. [2], [3], [4][6]).

\section{KESIMPULAN DAN SARAN}

This template is partly based on the IEEE extended abstract template.

\section{UCAPAN TERIMAKASIH}

The heading of the Acknowledgment section and the References section must not be numbered.

\section{DAFTAR PUSTAKA}

[1] S. M. Metev and V. P. Veiko, 1998, Laser Assisted Microtechnology, 2nd ed., R. M. Osgood, Jr., Ed. Springer-Verlag, Berlin, Germany.

[2] J. Breckling, Ed., 1989, The Analysis of Directional Time Series: Applications to Wind Speed and Direction, ser. Lecture Notes in Statistics, Vol. 61, Berlin, Germany: Springer.

[3] S. Zhang, C. Zhu, J. K. O. Sin, and P. K. T. Mok, 1999, A Novel Ultrathin Elevated Channel Low-Temperature Poly-Si TFT, IEEE Electron Device Lett., Vol. 20, pp. 569571, Nov.

[4] M. Wegmuller, J. P. von der Weid, P. Oberson, and N. Gisin, 2000, High Resolution Fiber Distributed Measurements with Coherent OFDR, in Proc. ECOC'O0, paper 11.3.4, p. 109.

[5] R. E. Sorace, V. S. Reinhardt, and S. A. Vaughn, 1997, High-speed Digital-to-RF Converter, U.S. Patent 5668 842, Sept. 16,

[6] 2002, The IEEE Website. [Online]. Available: http://www.iee.org/ 